\title{
Sermons to Address Obesity in Partnership With African American and Latino Churches
}

\author{
Denise D. Payán, PhD, MPP ${ }^{1}$; Karen R. Flórez, DrPH, $\mathrm{MPH}^{2}$; \\ Malcolm V. Williams, PhD, $\mathrm{MPP}^{3}$; Clyde W. Oden, OD, MPH, MDiv ${ }^{4}$; \\ Michael A. Mata, MA, MDiv, MCP ${ }^{5}$; Cheryl A. Branch, MS ${ }^{6}$; Margaret D. Whitley, $\mathrm{MPH}^{3}$; \\ Kathryn P. Derose, PhD, $\mathrm{MPH}^{3,7}$
}

\section{INTRODUCTION}

African American and Latino communities are disproportionately affected by obesity and diet-related diseases in the US. ${ }^{1}$ Faith-based organizations can be important partners in promoting health among African American and Latino congregants through infrastructure, programming, and strong social networks. ${ }^{2,3}$ Clergy, in particular, can provide public health information and promote healthy behaviors using their moral authority, visibility, and credibility. ${ }^{4-6}$

Health interventions that engage clergy can impact multiple levels in the socioecological model. ${ }^{7}$ Clergy can help individuals overcome intrapersonal barriers to healthy eating and physical activity by motivating and empowering them through role modeling and social support. They can also help improve social and built environments to encourage health-promoting behaviors among congregants and the community.
Integrating health messages into church sermons can leverage existing trust and shared values to reach vulnerable groups. A potential advantage is that sermons can target multiple levels of the socioecological theory ${ }^{8}$ and may help to address key intrapersonal barriers to healthy living-such as lack of motivation ${ }^{9}$ - through interpersonal influence. Clergy may also be better positioned to deliver health promotion messages to congregants than external facilitators ${ }^{2}$ as trusted messengers and health promoters at the intersection of health and spirituality. ${ }^{4}$ Limited faith-based health interventions describe integrating health messaging into sermons or evaluate implementation. ${ }^{2,3,6}$ Although most prior sermon interventions have been conducted in Judeo-Christian congregations, recent work in other faith communities (Muslim) indicates it is feasible and acceptable more broadly. ${ }^{10}$

This article presents a detailed description of the development and

\footnotetext{
${ }^{1}$ Department of Public Health, School of Social Sciences, Humanities and Arts, University of California Merced, Merced, CA

${ }^{2}$ Department of Environmental, Occupational, and Geospatial Health Sciences, Graduate School of Public Health and Health Policy, City University of New York, New York, NY

${ }^{3}$ RAND Corporation, Santa Monica, CA

${ }^{4}$ Bethel African Methodist Episcopal Church, Oxnard, CA

${ }^{5}$ Azusa Pacific Seminary, Los Angeles, CA

${ }^{6}$ Los Angeles Metropolitan Churches, Los Angeles, CA

${ }^{7}$ Department of Health Promotion and Policy, School of Public Health and Health Sciences, University of Massachusetts Amherst, Amherst, MA

Conflict of Interest Disclosure: The authors have not stated any conflicts of interest.

Address for correspondence: Denise D. Payán, PhD, MPP, Department of Public Health, University of California Merced, 5200 N Lake Rd, Merced, CA 95343;

E-mail: dpayan@ucmerced.edu

J Nutr Educ Behav. 2021;53:811-815

(C) 2021 The Authors. Published by Elsevier Inc. on behalf of Society for Nutrition Education and Behavior. This is an open access article under the CC BY-NC-ND license (http:// creativecommons.org/licenses/by-nc-nd/4.0/)

https://doi.org/10.1016/j.jneb.2021.04.469
}

implementation of healthy eating and physical activity sermons that were part of a multicomponent, church-based intervention for African American and Latino congregants in Southern California. The pilot evaluation used a cluster-randomized controlled trial in which churches $(n=6)$ were randomized to an intervention or waitlist (control) group. About 6 months after baseline data were collected, intervention participants demonstrated statistically significant less weight gain, greater weight loss, lower body mass index scores, and healthier diets. ${ }^{11}$ This article describes the sermon component, provides implementation evaluation results and discusses implications for research and practice.

\section{INTERVENTION DEVELOPMENT AND SERMON GUIDE DESCRIPTION}

The research team developed the faith-based intervention (Eat, Pray, Move) in collaboration with a multiethnic faith and public health partnership using a community-based participatory research approach. Two midsized (> 200 congregants) African American churches (Baptist, nondenominational) and a large Latino Roman Catholic church (> 2000 congregants) were randomized to receive the intervention. A detailed description of the study outcomes and other components are available elsewhere. $^{11-13}$

A 12-page sermon guide (Developing Sermons on Healthy Eating and Active Living) was developed by the research team and Steering Committee. The Steering Committee included 12 faith leaders, 2 public health leaders, and 3 public health 
researchers and was co-chaired by African American and Latino clergy. The guide contained publicly available evidence-based healthy eating and physical activity information, recommendations for action, and sample sermons with biblical references (Supplementary Data). The 4 overarching themes in the guide included project awareness, obesity awareness and policy context, healthy eating prompts, and active living prompts. The guide was developed in English and not translated because clergy at the Latino intervention church were bilingual with fluency in English. Table 1 provides the key themes in the guide and specific objectives.

Pastors from the 3 intervention churches were asked to deliver 2 sermons that included healthy eating and physical activity messages over 5 months. The purpose was to motivate congregants individually and collectively to address obesity and diabetes disparities through nutrition education and physical activity programs, policy, and community advocacy. Research staff met with each pastor to review the sermon guide and address any questions. Pastors were encouraged to tailor the sermon according to their style, content, and religious traditions to facilitate implementation.

\section{EVALUATION}

Pastors and church liaisons notified the research team when intervention sermons were scheduled. Because multiple services were held at each church on the weekend, research staff attended all Sunday services at each institution to collect data. Research staff audio recorded sermons and took detailed notes using an adapted version of a systematic religious observation questionnaire ${ }^{6,14}$ to gather information on attendance, message duration, and fidelity. Audio recordings were transcribed verbatim and analyzed by the lead author using an inductive approach.

Between December, 2015 and April, 2016, 5 unique sermons were delivered across the 3 churches. The Latino church pastor only delivered
1 sermon because he relocated in early 2016. Each sermon was delivered twice in the African American churches, whereas the same sermon in the Latino church was delivered by a bilingual clergy at 4 services ( 2 English and 2 Spanish). Although sermons in the Latino church reached the most congregants (on average and overall), sermon duration was considerably shorter than other churches, in part because of sermon length differences across faith traditions. Table 2 provides implementation results by intervention church and overall.

Assessing fidelity consisted of verifying if a sermon addressed 11 guide objectives. Sermons delivered at the Latino church met the fewest objectives ( $4 \%$ or $36 \%$ ), whereas those delivered in the African American churches met $>50 \%$ (range, 6-10). The nondenominational church pastor demonstrated the highest fidelity among participating clergy and was the sole leader to speak about the role of the broader environment, describing concepts like food deserts.

There was high fidelity across the churches (ie, clergy from all 3 churches met the objective at least once during a sermon) to the following objectives: mentioning church activities, sharing a personal story, and talking about the benefits of healthy eating/active living. Personal narratives were a common strategy used by all clergy. They referenced their own weight loss struggles and childhood memories of food, including cultural tendencies to use unhealthy food to reward behavior or accomplishments. Pastors also mentioned benefits to healthy eating and physical activity, like reduced chronic illness risk and improved quality of life. All pastors emphasized social support as a key facilitator for positive influence and accountability, prompting congregants to support and encourage one another in their efforts to improve their dietary behavior and increase their physical activity levels.

Nearly all other objectives had moderate fidelity and were met by at least 1 clergy in 2 of the 3 churches.
The sole objective with low fidelity consisted of mentioning supportive health education components. Refer to Table 1, which also includes fidelity results across churches and example quotes from the clergy.

Beyond the specific objectives from the sermon guide, clergy included faith-based strategies to overcome lack of motivation, such as the following quote from the nondenominational church pastor: "Activate your faith. Pray to God, 'this is my goal that I would like to be healthy. I want to see my grandbabies graduate.'" He then referenced 2 bible verses from the guide (Psalms 139:13-18; Philippians 4:13). The Baptist pastor similarly used prayer to motivate and encourage congregants: "Father help us to value our health, in the name of Jesus, we want to be healthy. We want to be strong."

\section{DISCUSSION}

Embedding health messages into sermons is a promising avenue to reach Latinos and African Americans. Results indicate clergy were receptive to delivering healthy eating and physical activity sermons from the pulpitadding to nascent work describing and evaluating sermons as health interventions. $^{6,15}$ Sermon interventions have several advantages because they center existing trustworthy sources of information in communities of color and do not have financial cost for implementation.

Guide fidelity varied by clergy with the highest fidelity to 3 objectives, including sharing a personal story about healthy eating/active living. This result is supported by a qualitative study investigating African American clergy perceptions about health promotion that found personal storytelling to be a popular communication method. ${ }^{4}$

\section{IMPLICATIONS FOR RESEARCH AND PRACTICE}

Strategies to improve fidelity include assessing readiness for participation or offer refresher training if there is a 


\section{Theme}

Project awareness and policy context

Healthy eating

(a) or active living

(b) prompts

\section{Specific Objective}

1 Mention church activities to promote healthy eating or active living

2 Discuss why the church is involved in this effort

3 Mention supportive health education components (eg, bulletin inserts, posters)

4 Share the date of any upcoming activities

5 Talk about how obesity or obesity-related diseases are affecting African American and/or Latino communities

6 Talk about the importance of policy and program advocacy

\section{Share a personal story about:}

a Healthy eating

b Active living

8 Talk about the role of the:

a Community food environment

b The built and social environment
Fidelity $^{\mathrm{a}}$

High

Moderate

Moderate

Moderate

"I want to start out by sharing some health disparity statistics for our community... heart disease is the leading cause of death for African Americans. Among non-Hispanic Blacks age 20 and older, 46\% suffer from cardiovascular disease" (Nondenominational AA church)

"70\% of African American neighborhoods and $81 \%$ of Latino neighborhoods lack recreational facilities compared to $38 \%$ of White neighborhoods" (Baptist AA church)

Moderate

"My family rewarded everything from good behavior to good grades to sports achievements with food. And we grew and grew...birthdays were cakes and ice-cream, right? You did well on a test, you got pizza or McDonalds" (Catholic Latino church) "My doctor told me, 'you need to lose 40 pounds. . you are overworking your body and you have extra weight on your body. My concern with you is you will drop dead from a massive heart attack without warning'" (Baptist AA church)

Moderate "One thing our community suffers from is what they call 'food deserts.' A food desert is where you have stores and markets that may not have the best meat or freshest vegetables. A food desert is where a community lacks nutritious options" (Nondenominational AA church)

"It is a challenge in our community-unhealthy foods are cheaper than healthy, organic food" (Baptist AA church) 

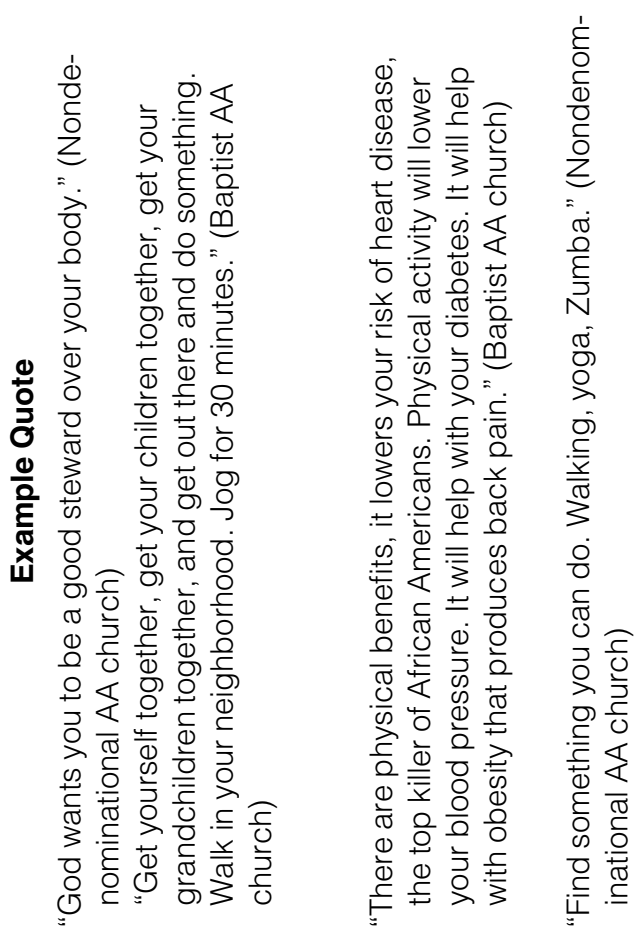

time lag between the initial overview of the intervention and delivery of a sermon. A larger evaluation trial could also assess the impact of the sermon intervention on the nutrition and physical activity knowledge, attitudes, and behaviors of participating clergy.

Researchers and practitioners can consider developing and testing different health messaging approaches in partnership with clergy, including addressing other health issues or different types of messaging (eg, personal stories compared with data about how an issue is affecting the community). An intervention study in Peru included a brief standardized message delivered by priests to reduce soda consumption with modest significant effects. ${ }^{15}$

Inviting clergy who will deliver the sermon, lay faith leaders, or congregants to help develop specific healthy eating and active living messages may increase their relevance to a particular congregation and/or faith community. Future research can focus on collecting data from congregants on the acceptability of sermon interventions and messaging, which were not included in this evaluation.
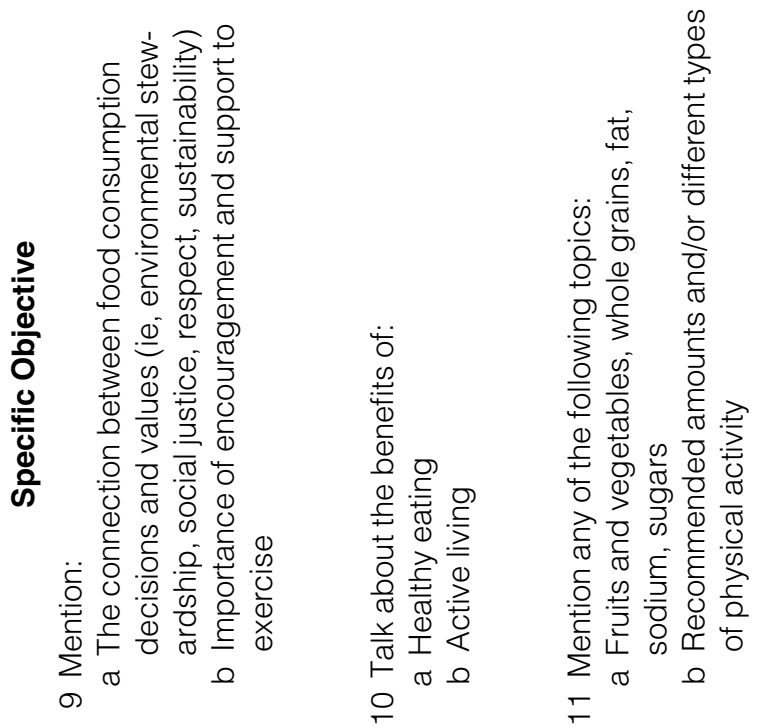

\section{NOTES}

The study procedures, materials, and protocols were approved by RAND's Human Subjects Protection Committee, which serves as the organization's Institutional Review Board. This study was funded by a grant from the National Institute on Minority Health and Health Disparities (grant no. R24MD007943). The authors would like to acknowledge contributions by members of the Community Steering Committee, especially the Rev Rosalynn Brookins, Rev John Cager, Rev Walter Contreras, Rev Jawane Hilton, Jaime Huerta, Rev Martín García, Dr Jan King, Rev Felipe Martínez, Bp Gwendolyn Stone, Nina Vaccaro, and Bp Craig Worsham. The authors thank project team members at RAND, including Marcela Gaither (graphic design of the sermon guide) and Jennifer Hawes-Dawson and Eunice Wong (comments on the sermon guide content). 
Table 2. Healthy Eating and Physical Activity Sermon Implementation Results by Church and Overall $(n=3$ churches)

\section{Measures}

Average and range of church attendance per service

Participating clergy

No. of unique sermons delivered

No. of church services impacted

Average and range of intervention sermon length in minutes

\section{Latino Catholic Church}

210 (70-350)

1
1
4
$12(11-12)$

\section{African American Baptist Church} 37 (23-50)

1
2
4
$37(33-40)$

African American Nondenominational Christian Church 64 (50-92) Overall $82(23-350)$
3

5 12 $33(11-51)$

Note: Values are $\mathrm{n}(\%)$. Data reflects observational data collected at 10 of 12 services held across the churches.

\section{SUPPLEMENTARY DATA}

Supplementary data related to this article can be found at https://doi. org/10.1016/j.jneb.2021.04.469.

\section{REFERENCES}

1. Hales CM, Carroll MD, Fryar CD, Ogden CL. Prevalence of obesity among adults and youth: United States, 20152016. NCHS Data Brief. 2017:288:1-8.

2. Flórez KR, Payán DD, Palar K, Williams MV, Katic B, Derose KP. Church-based interventions to address obesity among African Americans and Latinos in the United States: a systematic review. Nutr Rev. 2020;78:304-322.

3. Derose KP, Rodriguez C. A systematic review of church-based health interventions among Latinos. J Immigr Minor Health. 2020;22:795-815.

4. Lumpkins CY, Greiner KA, Daley C, Mabachi NM, Neuhaus K. Promoting healthy behavior from the pulpit: clergy share their perspectives on effective health communication in the African American church. $J$ Relig Health. 2013;52:1093-1107.

5. Baruth M, Bopp M, Webb BL, Peterson JA. The role and influence of faith leaders on health-related issues and programs in their congregation. I Relig Health. 2015;54:1747-1759.

6. Payán DD, Flórez KR, Bogart LM, et al. Promoting health from the pulpit: a process evaluation of HIV sermons to reduce HIV stigma and promote testing in African American and Latino churches. Health Commun. 2019;34:11-20.

7. Lancaster KJ, Carter-Edwards L, Grilo S, Shen C, Schoenthaler AM. Obesity interventions in African American faith-based organizations: a systematic review. Obes Rev. 2014;15(suppl 4): 159-176.

8. Sallis JF, Cervero RB, Ascher W, Henderson KA, Kraft MK, Kerr J. An ecological approach to creating active living communities. Annu Rev Public Health. 2006;27:297-322.

9. Payán DD, Sloane DC, Illum J, Lewis LB. Intrapersonal and environmental barriers to physical activity among Blacks and Latinos. J Nutr Educ Behav. 2019;51:478-485.

10. Padela AI, Malik S, Ahmed N. Acceptability of Friday sermons as a modality for health promotion and education. J Immigr Minor Health. 2018;20:1075-1084.

11. Derose KP, Williams MV, Flórez KR, et al. Eat, Pray, Move: a pilot cluster randomized controlled trial of a multilevel church-based intervention to address obesity among African Americans and Latinos. Am J Health Promot. 2019;33:586-596.

12. Whitley MD, Payán DD, Flórez KR, et al. Feasibility and acceptability of a mobile messaging program within a church-based healthy living intervention for African Americans and Latinos. J Health Inform. 2019;26:880896.

13. Payán DD, Derose KP, Flórez KR, Branch CA, Williams MV. The food environment in 3 neighborhoods in South Los Angeles, California: access, availability, quality, and marketing practices. Prev Chronic Dis. 2020;17:E61.

14. Derose KP, Bogart LM, Kanouse DE, et al. An intervention to reduce HIV-related stigma in partnership with African American and Latino churches. AIDS Educ Prev. 2014; 26:28-42.

15. Miranda JJ, Taype-Rondan A, BazalarPalacios J, Bernabe-Ortiz A, Ariely D. The effect of a priest-led intervention on the choice and preference of soda beverages: a cluster-randomized controlled trial in Catholic Parishes. Ann Behav Med. 2020;54:436-446. 